\title{
Study on Pathways of Improving the Affinity of Ideological and Political Education
}

\section{Hongzhi Liu}

\author{
College of Engineering, Bohai University, Jinzhou Liaoning, 121000, China
}

Keywords: ideological and political education; affinity; improvement pathway

\begin{abstract}
The principal method of improving the ideological and political education is to enhance the affinity, which is also the direction of the construction of ideological and political course. Such factors as the nature of ideological and political education, process and method of education, educator, educate, and even educational environment together are the affinity of ideological and political education. This paper mainly explores the pathways to improve the affinity of ideological and political education.

In December 2016, General Secretary Xi Jinping delivered a speech at the national conference on ideological and political education in colleges and universities, "Classroom teaching should be used as main method, ideological and political theory courses should be strengthened in improvement, and the affinity and pertinence of ideological and political education should be improved to meet the needs and expectations of students' growth and development”, which indicates the direction and pathway of ideological and political education in the future, and requirements. How to improve the affinity of ideological and political education is the problem that ideological and political educators need to carefully study.
\end{abstract}

\section{The importance of improving the ideological and political education}

The degree of intimacy, friendliness, and harmony between people is the affinity. The affinity of ideological and political education is the friendly relationship built by educators with students in course teaching to strengthen the trust between both sides and the cohesive force, so as to reach the recognition of students in the ideological and political education and achieve desired educational effects. In the social environment today, improving the affinity of ideological and political education is not only spurred by the social environment, but also it is the objective condition to be followed in ideological and political education, and an inevitable condition for the characteristics of the educatee.

\subsection{Environmental factor}

At present, the society is developing in all aspects, as for students obtaining higher education, their thinking is more active, their choices are more extensive and their values are more abundant. Nowadays, with the development of science and technology and the emergence of various networks and new media, students have obtained a lot of ways to communicate with the world, at the same time, which have also changed students' methods of communication. Therefore, new requirements have also emerged for students' ideological and political education. Traditional infusion teaching fails to meet their needs for ideological and political education. Students today generally have strong subjective consciousness. Compared with passive acceptance of various principles, they are more concerned with their own subjective feelings, and can only accept principles with guiding significance for them. Therefore, ideological and political education as a guide for student behavior, should be grounded to shorten the distance with students, create mutual trust, and embrace each other, so that the affinity of ideological and political education has been achieved.

\subsection{Rule requirement}

There is a certain degree of regularity in the ideological and political education, but no matter 
what kind of rules, the final premise is that ideological and political education must be full of the affinity. First of all, it is necessary for educators and educatees in ideological and political education to build a relationship of trust with each other. If educated people like educators, they can achieve an interactive relationship. Second, ideological and political education must be deeply rooted in people's minds. Educators must have a goal. Only strategic teaching can be accepted by students, and moral feelings, concepts, wills, and political beliefs are finally formed. Lastly, it is possible for ideological and political education with the affinity to play a role in self-influence process in a complicated social environment and become positive energy.

\subsection{Inevitable requirement}

From the age group of educatee, they are still in the growth stage of self-worth, and this period is when social values, and the way of life and communication change. They are the first generation with the rapid development of the network and information. Therefore, we should make use of the characteristics of the educatee themselves. Contemporary students grow in an era of openness and tolerance, with many characteristics that we don't have. We must recognize this and learn these characteristics, and become friends with them and shorten the distance between them. In this way, the goals of ideological and political education can be achieved while embracing each other to guide them with the scientific concept of ideological and political education, and gain the recognition of students.

\section{Cause for limiting the improvement in the affinity of ideological and political education}

First of all, due to the influence of economic globalization and multiple values in the Internet, the affinity of ideological and political education is gradually disappearing. The idea of economic globalization and Internet thinking have gradually made our country's social value orientation more active, and economic development has moved toward a new chapter, which has also led to the gradual intensification of social conflicts, surge of mainstream ideas and non-mainstream ideas, and diversified values of students, which has brought about negative effect on the ideological and political education and has reduced the affinity of ideological and political education. Second, due to the changes in the factors that make up the ideological and political education, the affinity of ideological and political education has weakened. The ideological and political education activities are composed of educators, educatee, educational environment, methods, and content. These factors can play a role in enhancing the affinity. However, the times are changing, and the nature of ideological and political education must also change. The affinity cannot be reduced because of the lack of standardization and ability to interpret the social environment, and the essence of ideological and political education cannot be lost because of the blind pursuit of novelty. The desired effect of ideological and political education cannot be achieved because of the lack of effective measures, and the improvement in the affinity will be limited because of the pertinence of ideological and political education. The pertinence is a prerequisite for the improvement in the affinity, ideological and political education can show affinity only if it is full with the pertinence. However, there is still a lack of pertinence in teaching. If the educators do not make preparations for teaching materials beforehand, they only blindly follow the books; some educators ignore the reality, and see phenomena more unilaterally, which will reduce the affinity of ideological and political education.

\section{Pathways to improve the affinity of ideological and political education}

The affinity of ideological and political education is the integration of emotional and rational affinity on the emotional level. Therefore, improving the affinity of ideological and political education should not only create emotional connections between educators and educatee, lay the emotional foundation for affinity, but also effectively combine the actual life of the educated people with the times, and strengthen the pertinence and timeliness when dealing with issues to improve rational affinity. 


\subsection{To create positive emotional connections based on practice}

From the perspective of philosophy, in fact, the ideological and political education is the spiritual communication and thinking integration between educators and educatee. To enhance the affinity of ideological and political education, we should focus on establishing emotional connections, controlling the key points of emotion in education, and creating a harmonious teaching model. Establish intimate contact in teaching. It is necessary to invest true emotions so that both sides of the education can participate in teaching activities with full emotions and they can enjoy teaching activities. To establish an intimate teaching connections, it is necessary to put the two parties on an equal status, build a harmonious teaching atmosphere, and respect and care for educatee. Care for disadvantaged groups, educate problem students with emotions, enhance mutual feelings, and improve affinity; integrate the characteristics of educators and educatee, create a harmonious teaching environment, and enhance the mutual spiritual distance. To deepen the analysis of the psychology of unique personality groups, to switch to different models for different students, find a common point, to strengthen their mutual contact and exchanges, so that they are all involved in the ideological and political teaching; master the key points of emotions in teaching. Educators should give concern and support for educatee to build more close relationship to enhance the affinity of ideological and political education.

\subsection{To improve the pertinence of ideological and political education based on life}

The ideological and political education is a spiritual teaching activity. Life-based is not only a condition for teaching, but also a teaching purpose. Experience life in person and we can deal with life issues and demonstrate the true value of ideological and political teaching. Therefore, to improve the affinity of ideological and political education, it is necessary to enter the student's life world, determine the focus of their life, find the key points of the problem, and deal with life issues is to improve the affinity and appeal of ideological and political education. The ideological and political education must demonstrate its true value and reflect its pertinence. Human beings live in this colorful life, so ideological and political education can show its connotations in life in order to express the requirements of human beings and increase the affinity and trust. In essence, ideological and political education should draw lessons from the daily lives of the learners and explain the knowledge that they want to know, focus on issues in life, use ideological and political education to guide practice to solve problems, so as to improve affinity; ideological and political education should be implemented to every subtle issue. Analyze the problem from the details, grasp the ideological dynamics, so as to obtain key information; focus on details, and every step in the teaching must be perfect. The ideological and political education should be based on both big and subtle issues in life, explore key points in life, use principles to solve daily problems, and practice in life, realize the dream, and make ideological and political education win people's heart and increase the affinity.

\subsection{To improve the timeliness of ideological and political education based on times}

In essence, ideological and political education is closely linked with the fate of the Communist Party of China. As stressed by General Secretary Xi Jinping, the ideological and political education in colleges and universities must be based on the times and be innovative. The ideological and political education conforms to the changes of the times and adjust the methods, and it is possible to strengthen the pertinence and ensure its own affinity and vitality. To adjust to the times and conduct specific analysis on specific issues. First of all, in the face of the complex and ever-changing situation, ideological and political education must also change, from person to person and from case to case. Secondly, to see the substance, distinguish between primary and secondary, and not be confused. Lasty, it is not only necessary to care about state affairs, but also to be good at grasping the reality and to handle the small matters closely linked with the masses and reach deep inside. It is also necessary to teach students at different levels and make specific analysis according to different problems. Bring education into practice and we can improve our affinity and appeal; and we can advance with the times. The ideological and political education must follow the times, integrate 
contemporary ideological spirits into ideological and political education, improve the timeliness of education, and grasp the opportunity for development, and work hard in the era of constant innovation. It is also necessary to grasp the timing of education, conform to the development of the times, approach real education, and strengthen the influence and vitality of ideological and political education in the development in a new era; Conduct the reform and innovation with the times. As for ideological and political education, it is necessary to understand the environmental situation and grasp the new direction of development, prove itself in constant innovation, and make education more appealing and vital. Follow the direction of the development of the times, and the pertinence and avant-garde of ideological and political education can be shown, and the affinity of ideological and political education can be enhanced.

\section{Conclusion}

For recent years, with the support of the National Ministry of Education, the way of ideological and political teaching has undergone great changes, and the affinity of ideological and political education has also been greatly improved, which has also promote the educated people to learn ideological and political knowledge and the learning effect is desired. In the future, the affinity of ideological and political education shall be improved to guide everyone to learn more ideological and political coursed under the affinity.

\section{Acknowledgements}

Bohai University educational reform research program (student work special project) porject No. 2017 XZHB1.

\section{References}

[1] Xi Jinping. Integrate the Ideological and Political Education into the Whole Process of the Educational Teaching, Create New Situation of the Development of National Higher Education [N]. People's Daily, 2016, 12-09.

[2] Commentator. Improve the Affinity and Pertinence of Ideological and Political Education [N]. Guangming Daily, 2016, 12-11 (1).

[3] Chen Wanbai, Zhang Yaocan. Ideological and Political Education Theory (The 2rd Version) [M]. Beijing: Higher Education Press, 2007.

[4] Bai Xianliang. On the Logical Generation of the Affinity of Ideological and Political Theory Teaching in Colleges and Universities [J]. Journal of Ideological and Theoretical Education, 2017 (4). 